MATEC Web of Conferences 11, 01047 (2014)

DOI: $10.1051 /$ matecconf/ 20141101047

(C) Owned by the authors, published by EDP Sciences, 2014

\title{
Erratum to: Diffusion of nitrogen in austenitic phase: Application to nitriding of stainless steels
}

Lazhar Torchane and Okba Belahssen

Université de Tébessa, Faculté des Sciences et de la Technologie, Département de Génie Mécanique, Tébessa, Algérie

Original article:

MATEC Web of Conferences 11, 01030 (2014), DOI :10.1051/matecconf/20141101030

The name of the last author should be Okba Belahssen. unrestricted use, distribution, and reproduction in any medium, provided the original work is properly cited. 